\title{
PENINGKATAN PEMAHAMAN KONSEP SAINS DI MADRASAH IBTIDAIYAH MELALUI PERBAIKAN BAHAN AJAR
}

\author{
Agus Mukti Wibowo \\ Dosen Tetap Jurusan PGMI Fakultas Tarbiyah UIN Maliki Malang
}

\begin{abstract}
Understanding is very important in science learning, especially at the level of Madrasah Ibtidaiyah. Students' concepts understanding tend to similarity to the explanations and examples provided by the teacher or teaching materials. In fact, most teaching materials and textbooks are not reviewer both in terms of content and material. Corrected and modified teaching material to be improved students' understanding.
\end{abstract}

Keywords: Teaching Materials, Concept Understanding, Science Learning.

\section{A. Pendahuluan}

Pemahaman merupakan salah satu faktor penting dalam belajar khususnya di madrasah ibtidaiyah. Menurut Nakhleh (19192:191) kesulitan-kesulitan dalam memahami konsep-konsep dasar dengan tepat akan menghambat siswa dan mahasiswa dalam mengkaitkan konsep-konsep dasar tersebut dengan konsep-konsep lain yang berhubungan. Kondisi ini dapat memungkinkan timbulnya pemahaman yang salah terhadap suatu konsep. Jika kesalahan yang ada terjadi secara terus menerus (konsisten) maka dapat dikatakan mengalami kesalahan konsep (misconception) (Berg, 1988:26). Konsistensi kesalahan dapat diidentifikasi dengan mengujikan beberapa soal dengan dasar konseptual yang sama atau dengan melihat konsistensi jawaban tes tertulis dengan wawancara. Kesalahan dalam pembelajaran sains yang terjadi secara terus menerus pada siswa tingkat dasar atau madrasah ibtidaiyah akan lebih sulit untuk dihilangkan.

Menurut Bodner (1992) bahwa dalam kegiatan pembelajaran, terutama dalam pembelajaran tingkat dasar atau madrasah ibtidaiyah, perbaikan kesalahan konsep tidak mudah dilakukan, karena konsep 
yang salah tersebut sukar untuk ditinggalkan. Pernyataan ini identik dengan pendapat Carey (dalam Suparno, 1997) bahwa usaha untuk mengubah kesalahan pemahaman bukanlah sesuatu yang mudah. Perubahan pemahaman suatu konsep yang salah baru berhasil jika terjadi proses rekonstruksi yang kuat. Salah satu cara perubahan konsep menurut Posner, Strike, Hewson \& Gerzog (1982) yaitu dengan menimbulkan suatu peristiwa atau anomali yang bertentangan dengan apa yang dipikirkan siswa, sehingga akan terjadi ketidakpuasan siswa terhadap konsep lama dan pada akhirnya akan mengubah konsep tersebut.

Pemberian peristiwa atau anomali yang bertentang dengan yang dipikirkan siswa tidak harus menggunakan suatu strategi, metode atau pendekatan pembelajaran saja, tetapi dapat juga digunakan suatu materi yang mencakup peristiwa atau anomali tersebut. Hal ini desebabkan pada siswa tingkat pendidikan dasar atau madrasah ibtidaiyah kemampuan berfikir abstrak masih sangat rendah, maka diperlukan contoh-contoh yang konkrit dalam materi yang diberikan dalam pembelajaran.

Proses belajar mengajar, baik di sekolah maupun di bimbingan belajar, tidak terlepas dari bahan ajar atau buku teks. Penjelasan konsepkonsep ilmu sains yang diberikan dalam buku teks seringkali salah atau kurang dan konsep yang dijelaskan cenderung disederhanakan.

Menurut Herron (1975:149) perbaikan kesalahan dengan model untuk mengkonkritkan materi yang dipelajari memiliki kelebihan karena dapat membantu mahasiswa berpikir sampai tingkat mikroskopis, mengkonstruk pengetahuan dan mengubah pola pikir ke arah lebih baik. Walaupun demikian perlu kehati-hatian dalam penggunaannya karena dalam beberapa hal penggunaan model yang salah dalam pembelajaran justru dapat menyebabkan kesalahan konsep baru (Bent, 1984:774). Menurut Greca \& Moreira (2000) proses belajar bermakna dalam memahami konsep yang sesuai dengan model mental dapat berhasil dengan baik apabila melalui pemodelan. Pembelajaran remidi dengan menggunakan materi yang telah diperbaiki kesalahannya dan ditambah kekurangannya menunjukkan peningkatan prestasi belajar siswa secara signifikan. Hal ini kemungkinan disebabkan materi yang diberikan pada pembelajaran remidi mampu merubah atau mengurangi kesalahan 
konsep yang terjadi pada siswa.

Analisis kesalahan atau kekurangan terhadap sumber belajar, dalam hal ini bahan atau buku-buku yang dipakai dalam pembelajaran dan perbaikan kesalahan konsep siswa dengan menggunakan bahan ajar yang mencukupi dari segi materi sangat jarang dilakukan. Para pengajar (guru) di mata pelajaran sains atau Ilmu Pengetahuan Alam cenderung langsung memanfaatkan buku-buku teks yang tersedia sebagai bahan ajar dalam pemebelajaran. Untuk itu perlu adanya pengembangan bahan ajar sains yang memiliki kecukupan materi.

\section{B. Pengertian dan Karakteristik Sains}

Beberapa ahli mendifinisikan konsep dalam berbagai pengertian. Menurut Winkel (1987:87) konsep merupakan suatu arti yang mewakili sejumlah obyek yang mempunyai ciri-ciri yang sama. Menurut Gillbert dan Watts (1983:65) mendefinisikan konsep sebagai bagian dari properti-properti umum di mana properti-properti tersebut dianggap cukup dan perlu untuk menentukan suatu konsep. Menurut Berg (1991:8) konsep sebagai abstraksi dari ciri-ciri sesuatu yang mempermudah komunikasi antar manusia dan memungkinkan manusia untuk berfikir. Dengan demikian konsep merupakan gagasan yang memiliki arti yang menggambarkan ciri-ciri umum dalam bentuk simbol, peristiwa atau sekumpulan obyek dengan ciriciri tertentu yang dapat mempermudah komunikasi antar manusia serta memungkinkan manusia untuk berfikir. Selain itu White (dalam Gillbert dan Watts (1983:65) berpendapat bahwa konsep akan menjadi unit-unit kesadaran dalam suatu sistem kognitif yang lebih statis dan tidak berubah-ubah.

Menurut Vygotsky (dalam Wertsch, 1985:102) konsep ada dua kategori, yaitu konsep spontan, yang merupakan konsep yang diperoleh dari kehidupan sehari-hari dan konsep ilmiah yang diperoleh dari pelajaran di sekolah. Sedangkan Gagne (dalam Dahar 1989), konsep ada dua jenis, yaitu (1) konsep konkrit, yaitu abstraksi atau gagasan yang ditemukan dari obyek atau peristiwa konkrit, misalnya konsep pemuaian, pemanasan. (2) Konsep terdifinisi, yaitu konsep yang diturunkan dari obyek abstraksi, contohnya konsep tentang pengukuran panjang dan waktu dalam menentukan kecepatan maupun percepatan. Freybery dan Osborne (dalam Gillbert dan Watts, 1983:66) menggambarkan konsep seperti cara mengorganisir 
pengalaman kita sehingga pengalaman baru tidak meninggalkan konsep secara utuh tetapi seluruh pembelajaran kognitif yang terdiri dari beberapa tingkat konseptual kembali dari ilmu pengetahuan yang telah ada. Selanjutnya, perkembangan konsep dapat terlihat sebagai suatu proses perbedaan yang bersifat kreatif, aktif dan terus menerus serta tidak ada yang bersifat statis dan tidak dapat diubah (Kelly dalam Gillbert dan Watts, 1983:66).

Konsep dalam ilmu sains memiliki karakteristik tertentu. Sastrawijaya (1988:87) menyatakan konsep dalam sains merupakan konsep yang berjenjang dari yang sederhana ke konsep yang lebih tinggi tingkatannya. Sehingga dalam memahami konsep yang lebih tinggi diperlukan pemahaman yang benar terhadap konsep yang membangun konsep tersebut. Misalnya untuk memahami konsep tentang kecepatan maka diperlukan pemahaman yang benar tentang konsep-konsep lain yang mendasarinya, antara lain pemahaman konsep tentang jarak perpindahan benda maupun gerak benda.

Menurut Middlecamp dan Kean (1984:4) konsep sains memiliki karakteristik (1) sebagian besar konsep sains bersifat abstrak, (2) konsep-konsep sains pada umumnya merupakan penyederhanaan dari keadaan yang sebenarnya, (3) konsep sains bersifat berurutan.

\section{Definisi dan Fungsi Bahan Ajar (Buku Teks) Sains}

Bacon (dalam Tarigan, 1989:11) menjelaskan bahwa bahan ajar dalam hal ini buku teks adalah buku yang dirancang untuk digunakan di kelas, disusun secara cermat dan disiapkan oleh para ahli dalam bidang yang bersangkutan serta dilengkapi sarana dan prasarana pengajaran yang sesuai dan serasi. Buku teks merupakan buku standar dalam bidang tertentu yang disusun oleh para ahli dalam bidang tertentu dan tujuan instruksional dan dilengkapi dengan sarana pengajaran yang serasi dan mudah dipahami oleh para pemakainya di sekolah atau di perguruan tinggi sehingga dapat menunjang sesuatu program pengajaran (Tarigan, 1989:13). Pengertian buku teks seperti dikemukakan oleh Bacon (dalam Tarigan, 1989:13) dapat dianggap kurang tepat. Pengertian yang lebih tepat adalah bahan ajar atau buku teks merupakan bahan pembelajaran atau buku yang disusun oleh para ahli dibidangnya dan juga ditelaah oleh orang-orang yang juga ahli dibidang tersebut, sehingga isi dari materi yang ada dalam bahan ajar atau buku teks tersebut dapat dipertanggungjawabkan 


\section{Agus Mukti Wibowo - Peningkatan Pemahaman Konsep ...}

kebenarannya.

Buku teks mempunyai peranan yang penting dalam membantu siswa memahami konsep tertentu selain mendapatkan pengajaran di kelas. Menurut Greene dan Petty (dalam Tarigan, 1989:17) buku teks dalam GBPP mempunyai peranan, antara lain:

1. Mencerminkan suatu sudut pandang yang tangguh dan modern mengenai pengajaran serta mendemonstrasikan aplikasinya dalam bahan pengajaran yang disajikan.

2. Menyajikan suatu sumber pokok masalah atau subject matter yang kaya, mudah dibaca dan bervariasi yang sesuai dengan minat kebutuhan para siswa dan sebagai dasar bagi programprogram kegiatan yang disarankan dimana ketrampilanketrampilan ekspresional diperoleh di bawah kondisi-kondisi yang menyerupai kehidupan yang sebenarnya.

3. Menyediakan suatu sumber yang tersusun rapi dan bertahap mengenai ketrampilan-ketrampilan ekspresional yang mengemban masalah pokok dalam komunikasi.

4. Menyajikan metode-metode dan saran-sarana pengajaran untuk memotivasi para siswa, bersama-sama dengan buku teks lain yang mendampinginya.

5. Menyajikan fiksasi (perasaan yang mendalam) awal yang perlu dan juga sebagai penunjang bagi latihan-latihan dan tugas-tugas praktis.

6. Menyajikan bahan atau sarana evaluasi dan remidial yang serasi dan tepat guna.

Dalam kegiatan belajar mengajar peranan bahan ajar maupun buku teks juga sangat penting, antara lain:

1. Sebagai sumber belajar. Bahan ajar maupun buku teks berperan sebagai revisi bagi siswa jika seorang siswa mempunyai pertanyaan yang belum bisa dijawab oleh siswa sendiri, maka siswa dapat mencari jawabannya di dalam buku teks.

2. Penyedia petunjuk kegiatan. Pada dasarnya konsep-konsep sain diperoleh melalui kegiatan observasi, pengamatan dan eksperimen, karena itu bahan ajar maupun buku teks sain perlu diberi petunjuk kegiatan. 


\section{Agus Mukti Wibowo - Peningkatan Pemahaman Konsep ...}

3. Pendorong motivasi siswa. Bahan ajar maupun buku teks dapat memberi motivasi bagi siswa jika penyajian masalahnya menarik, disertai dengan penjelasan yang konkrit dan dapat membimbing siswa untuk bertanya serta ingin tahu sehingga siswa terdorong untuk mencari jawabannya.

4. Penyedia pertanyaan-pertanyaan. Pertanyaan-pertanyaan yang disajikan dalam bahan ajar dapat berupa evaluasi untuk mengetahui apakah siswa telah menguasai konsep dan materi atau dengan tujuan untuk pengayaan. Pertanyaan-pertanyaan tersebut biasanya pada tiap akhir pokok bahasan.

5. Penghubung materi pelajaran dengan pengalaman kehidupan sehari-hari. Penyajian materi bahan ajar diusahakan adanya keterkaitan materi pelajaran yang ada dengan pengalaman siswa dalam kehidupan sehari-hari.

\section{Kesalahan Bahan Ajar (Buku Teks) Sains}

Kesalahan yang terjadi dalam mempelajari ilmu sains secara umum dapat dibagi menjadi beberapa jenis, yaitu (1) kesalahan yang terjadi secara acak tanpa sumber tertentu (misalnya salah hitung atau salah menuliskan rumus), (2) salah ingat atau hafal, dan (3) kesalahan yang terjadi secara terus menerus serta menunjukkan kesalahan dengan sumber-sumber tertentu. Kesalahan jenis ketiga inilah yang biasa disebut kesalahan konsep (Berg, 1991). Kesalahan konsep tersebut tidak hanya terjadi pada siswa, tetapi memungkinkan terjadi juga pada guru atau sumber belajarnya, yaitu buku teks atau bahan ajar. Kesalahan atau kekurangan dalam buku teks atau bahan ajar kemungkinan dapat meyebabkan kesalahan konsep pada siswa yang menggunakannya.

Kesalahan konsep dalam sain adalah satu hal mendasar. Kesalahan konsep yang terjadi dapat disebabkan oleh banyak faktor, diantaranya adalah interaksi siswa dengan guru atau dengan bukubuku pelajaran. Kesalahan konsep menurut Dahar (1989), dapat timbul jika tidak ada kemampuan mengkaitkan antara konsep satu dengan konsep yang lain sehingga mengakibatkan proporsi yang salah. Berg (1991) mengemukakan bahwa terjadinya kesalahan konsep dapat pula disebabkan oleh gagasan-gagasan yang muncul dalam pikiran seseorang. 
Hasil dari proses pembelajaran di kelas dengan apa yang diperoleh siswa dengan membaca buku teks atau bahan ajar, kemungkinan siswa akan memadukan konsep yang diperoleh atau siswa tidak terpengaruh dengan hasil pembelajaran di kelas. Menurut Ibnu (1989:27) kemungkinan yang terjadi akibat adanya konflik tersebut adalah (1) tetap berpegang pada konsep lama dan menolak sepenuhnya konsep baru yang diperkenalkan (2) memahami konsep baru secara tidak utuh, dikombinasikan dengan aspek-aspek konsep yang lama atau digunakan secara bergantian dalam situasi yang dianggap cocok (3) mengadopsi secara utuh konsep yang baru dan meninggalkan konsep yang lama.

Kesalahan konsep dalam belajar sains akan mengakibatkan lemahnya penguasaan terhadap materi secara utuh. Kesalahan pada konsep dasar akan mengakibatkan kesulitan dalam penguasaan konsep selanjutnya, mengingat urutan materi dalam pelajaran sains tersusun secara hirarkis dan berjenjang, konsep satu menjadi dasar konsep yang lain. Jika sumber belajar (dalam hal ini bahan ajar maupun buku teks) terdapat kesalahan konsep maka dimungkinkan siswa atau guru akan mengalami kesalahan konsep.

Bahan ajar maupun buku teks sains merupakan bahan pembelajaran maupun buku pelajaran dalam bidang sains yang disesuaikan dengan kurikulum, yang disusun oleh ahli dalam bidang sain. Penulis bahan ajar maupun buku sering memberikan penjelasan yang kurang tepat atau kurang memadai. Kesalahan-kesalahan dalam buku teks sains kebanyakan adalah kesalahan-kesalahan yang sangat mendasar. Seringkali hal ini disebabkan oleh adanya penyederhanaan dalam penjelasan yang diberikan oleh penulis buku atau referensi penulis buku yang sudah terlalu lama dan tidak sesuai lagi dengan perkembangan ilmu pada masa sekarang.

Dalam prakteknya, kebanyakan buku teks di Indonesia memiliki kelemahan yaitu kurang atau tidak adanya pereview buku teks dari segi isi dan materi. Dari kelemahan tersebut kemungkinan terjadi kesalahan-kesalahan dalam contoh-contoh dan penjelasan yang diberikan dalam buku-buku sains, dan ini memerlukan analisis yang lebih jauh. 
Agus Mukti Wibowo - Peningkatan Pemahaman Konsep ...

\section{E. Pemahaman Konsep dalam Ilmu Sains}

Seperti halnya sebuah bangunan, tidak mungkin berdiri kokoh jika hanya berdiri sendiri tanpa adanya penopang lain di sekitarnya. Setiap konsep juga tidak mungkin berdiri sendiri, tetapi harus saling berhubungan antara konsep yang satu dengan konsep yang konsep yang lain. Konsep-konsep tersebut membentuk semacam jaringan yang saling berkaitan membentuk suatu pengetahuan di dalam kepala manusia. Seringkali dalam belajar siswa hanya menghafalkan konsep secara definitif tanpa memperhatikan fakta atau hubungan antar konsep. Dengan demikian konsep baru tersebut akan sulit untuk masuk dalam jaringan konsep yang telah ada, melainkan akan berdiri sendiri tanpa ada hubungan dengan konsep yang lain. Kondisi ini dapat memungkinkan siswa mengalami kesalahan dalam memahami konsep yang dipelajari atau miskonsepsi.

Uraian di atas menunjukkan bahwa pemahaman konsep dapat didefinisikan sebagai pemahaman oleh siswa atas konsep-konsep yang sama dengan apa yang dimaksud oleh buku acuan (bahan ajar yang tepat) atau para ahli (masyarakat ilmiah) secara konsisten. Jika mereka meiliki pemahaman yang berbeda dan terjadi secara konsisten maka dapat dikatakan bahwa mereka mengalami kesalahan konsep. Kesalahan konsep yang terjadi pada siswa dapat terjadi akibat interaksi antara siswa dan guru atau dengan buku-buku pelajaran (Griffiths dan Preston, 1992). Kesalahan konsep tersebut jika tidak diperbaiki akan menggangu pemikiran siswa dalam menerima pengetahuan berikutnya. Oleh karena itu perlu dilakukan perbaikan untuk meningkatkan pemahaman konsep siswa dengan benar.

\section{F. Teori Perubahan Konsep}

Upaya untuk merubah kesalahan konsep tidaklah mudah. Hal ini terjadi karena kesalahan konsep cenderung konsisten (Berg, 1991). Kesalahan konsep dapat dirubah apabila melalui rekonstruksi yang kuat (Carey dalam Suparno, 1997).

Posner, Strike, Hewson dan Gertzog (1982) mengajukan teori perubahan konseptual berdasarkan pandangan konstruktivistik dan Piaget melalui dua fase yaitu asimilasi dan akomodasi. Model belajar yang dikembangkan Posner, Strike, Hewson dan Gertzog (1982) menggunakan ide "paradigma" dari Thomas Khun dan teori "hard 
core" dari Irme Lakatos.

Asimilasi yang merupakan fase pertama terjadi apabila individu menggunakan konsep yang ada untuk menghubungkan dengan fenomena baru sedangkan fase kedua yaitu akomodasi terjadi apabila individu tidak mampu menghubungkan konsep-konsep yang ada dengan fenomena atau pengalaman baru sehingga individu harus mengatur kembali konsep intinya. Dalam pengaturan kembali konsep, tidak semua konsep diganti. Individu akan menyimpan konsepkonsep yang ada dan beberapa dari konsep tersebut akan berfungsi untuk memberikan petunjuk proses perubahan konseptual. Bentuk dari perubahan konsep yang radikal menurut Posner, Strike, Hewson dan Gertzog (1982) adalah melalui proses akomodasi.

Agar proses akomodasi dapat terjadi ada empat kondisi penting yang harus dipertimbangkan yaitu :

1. Harus ada ketidakpuasan terhadap konsep yang ada.

2. Konsep baru harus dapat dipahami.

3. Suatu konsep yang baru pada awalnya harus nampak masuk akal.

4. Konsep baru seharusnya menunjukkan keberhasilan suatu riset.

Agar proses akomodasi dapat tercapai maka perlu pengembangan jenis-jenis strategi dalam proses pembelajaran (Posner, Strike, Hewson dan Gertzog,1982). Selain itu penggunaan bahan ajar yang mencukupi dari segi materi dapat juga dilibatkan dalam pembelajaran. Dengan adanya bahan ajar yang mencukupi dari segi materi kemungkinan proses akomodasi dan asimilasi dapat tercapai.

\section{G. Pentingnya Pengembangan Materi Sains Secara Tepat}

Dalam mempelajari ilmu sains, siswa banyak dikenalkan materi dengan konsep-konsep yang abstrak (Wiseman, 1981), maka untuk pengungkapan konsep yang abstrak tersebut guru atau dalam buku teks memberikan gambaran atau definisi yang mewakili konsep tersebut. Hal ini menunjukkan bahwa bahan ajar yang kurang tepat akan kemungkinan dapat mengakibatkan kesalahan pemahaman pada siswa. Menurut Ibnu (1989) kadangkala siswa mengidentikkan antara konsep sebenarnya dengan obyek yang dijadikan sebagai gambaran konsep tersebut. Hal ini akan menyulitkan siswa dalam 
memahami konsep dari materi yang dipelajari dari bahan ajar atau bahkan berimplikasi pada salah satu konsep. Di samping abstrak, konsep dalam ilmu sains dapat memiliki arti lebih dari satu arti dan setiap konsep tidak dapat berdiri sendiri seperti pada contoh karakteristik konsep sains. Fenomena ini menunjukkan pentingnya bahan ajar yang tepat dan memiliki kecukupan materi sehingga siswa memiliki pemahaman konsep yang benar dalam mempelajari konsepkonsep dalam ilmu sains.

Pemahaman konsep yang benar merupakan landasan yang memungkinkan terbentuknya pemahaman yang benar terhadap konsep-konsep lain yang berhubungan atau konsep yang lebih kompleks, fakta, hukum, prinsip dan teori-teori dalam ilmu sains. Terlebih lagi jika diingat bahwa salah satu karakteristik dari konsep ilmu sains adalah adanya saling keterkaitan dan berkembang dari konsep yang sederhana menuju konsep yang lebih kompleks (Middlecamp dan Kean, 1989:8; Sastrawijaya, 1988:103). Pemahaman suatu konsep yang tidak benar memungkinkan terbentuknya konsepkonsep lain yang berkaitan tidak benar pula.

Menurut Dahar (1989:79), untuk dapat memecahkan masalah seseorang harus mengetahui aturan-aturan yang relevan dan aturanaturan ini didasarkan pada konsep yang diperolehnya. Dengan demikian dapat dikatakan bahwa konsep merupakan landasan dalam berfikir, sehingga pemahaman konsep yang benar menjadi sangat penting untuk dimiliki. Pemahaman konsep yang benar merupakan landasan dalam memahami fakta-fakta, hukum-hukum, prinsip-prinsip dan teori-teori dalam ilmu sains secara benar. Selain itu, pemahaman konsep secara benar akan menghasilkan penerapan konsep yang benar sebagai landasan untuk memecahkan masalah dalam kehidupan sehari-hari dan iptek yang sangat cepat perkembangannya. Pemahaman konsep yang benar ini tentunya membutuhkan konsep yang benar dan memiliki kecukupan materi dari bahan ajar yang digunakan dalam pembelajaran.

Pemahaman konsep yang dimiliki oleh siswa cenderung memiliki kemiripan dengan penjelasan maupun contoh yang diberikan oleh pengajar (guru) maupun bahan ajar atau buku teks yang digunakan. Hal menunjukkan adanya indikasi bahwa pemahaman konsep yang terjadi pada siswa kemungkinan bersumber dari buku-buku atau bahan 
ajar sains yang dipergunakan dalam pembelajaran. Pembelajaran dengan menggunakan materi yang telah diperbaiki kesalahannya dan ditambah kekurangannya dimungkinkan akan mampu meningkatkan pemahaman konsep siswa dengan benar.

\section{H. Penutup}

Pemahaman yang diperoleh siswa dalam pembelajaran sain di tingkat Madrasah Ibtidaiyah dimungkinkan karena pengaruh dari bahan jar yang digunakan dalam pembelajaran. Jika bahan ajar yang digunakan tidak tepat makan akan mengakibatkan kesalahan pemahaman atau miskonsepsi pada siswa. Untuk itu diperlukan pengembangan bahan ajar yang tepat baik dari segi isi maupun materi. Pengembangan bahan ajar yang tepat dimungkinkan akan mampu meningkatkan pemahaman konsep siswa dengan benar.

\section{Daftar Pustaka}

Bent, H.A. 1984. "Uses (and Abuses) Model in Teaching Chemistry". Journal of Chemical Education, 61(9): 774-776.

Berg, V.D. 1991. Miskonsepsi Fisika dan Remidiasi. Sebuah Pengantar Berdasarkan Lokakarya di Universitas Kristen Satya Wacana Salatiga 7 - 10 Agustus 1990. Salatiga: Universitas Kristen Satya Wacana.

Bodner, G.M. 1992. "Why Changing The Curriculum May Not Be Enough". Journal of Chemical Education, 69(3): 186-190.

Dahar, R.W. 1988. Teori-Teori Belajar. Jakarta: P2LPTK.

Gilbert, J.K. \& Watts, D.M. 1983. “Concepts, Misconceptions and Alternative Conceptions: Changing Perspectives in Science Education". Studies in Science Education, 10: 61-98.

Greca, I.M. \& Moreira, M.A. 2000. “Mental models, Conceptual models and Modelling". International Journal of Science Education, 22(1): $1-11$.

Griffiths, A.K. \& Preston, K.R. 1992. “Grade-12 Student's Misconceptions Relating to Fundamental Characteristics of Atoms and Molecules". Journal of Research in Science Teaching, 29(6): 611-628.

Herron, D. J. 1975. “Piaget for Chemists: Explaining What 'Good' 
Agus Mukti Wibowo - Peningkatan Pemahaman Konsep ...

Student cannot Understand. Journal of Chemical Education, 52(3): 146-150.

Ibnu, S. 1989. Kesalahan Atas Konsep-Konsep IPA Karena Ketidaktepatan Pendekatan Yang Digunakan. Kumpulan Makalah. Malang.

Middlecamp, C. \& Kean, E. 1985. Panduan Belajar Sains Dasar. Jakarta: Gramedia.

Nakhleh, M.B. 1992. “Why Some Student's Don't Learn Chemistry: Chemical Misconceptions". Journal of Chemical Education, 69 (3): 191-195.

Posner, G.J., Strike, K.A., Hewson, P.W. \& Gertzog, W.A. 1982. "Accomodation of A Scientific Conception: Toward A Theory of Conceptual Change". Science Education, 66(2): 211-227.

Posner, G.J., \& Gertzog, W.A. 1982. "The Clinical Interview and the Measurement of Conceptual Change". Science Education, 66(2): 195-209.

Sastrawijaya, T. 1998. Proses Belajar Mengajar Sains. Jakarta: Depdikbud.

Suparno, P.1997. Filsafat Konstruktivisme Dalam Pendidikan. Yogyakarta: Kanisius.

Tarigan, H.G. \& Tarigan, D. 1986. Telaah Buku Teks Bahasa Indonesia. Bandung: Angkasa Bandung.

Wertsch, J.V.1985. Vygotsky and the Social Formation of Mind. Cambridge Mass: Havard University Press.

Winkel, W.S. Psikologi Pengajaran. 1989. Jakarta: Gramedia.

Wiseman, F.L. 1981. "The Teaching of College Chemistry: Role of Student Development Level". Journal of Chemical Education, $58(6)$ : 484-488.

172 Madrasah, Vol. 4 No. 2 Januari - Juni 2012 